\title{
Plant and Endophyte Effect on Fiber, $N$, and $P$ Concentrations in Tall Fescue
}

\author{
James K. Rogers, ${ }^{1}$ Ben C. Morton, ${ }^{2}$ and Jagadeesh Mosali ${ }^{1}$ \\ ${ }^{1}$ The Samuel Roberts Noble Foundation, 2510 Sam Noble Parkway, Ardmore, Ok 73401, USA \\ ${ }^{2}$ Clemson University, 540 E. Main Street, Pendleton, SC 29670, USA
}

Correspondence should be addressed to Jagadeesh Mosali, jmosali@noble.org

Received 8 February 2011; Accepted 27 March 2011

Academic Editor: Robert J. Kremer

Copyright (C) 2011 James K. Rogers et al. This is an open access article distributed under the Creative Commons Attribution License, which permits unrestricted use, distribution, and reproduction in any medium, provided the original work is properly cited.

Tall fescue (Lolium arundinaceum) infected with an endophyte (Neotyphodium spp.) generally has agronomic advantages over endophyte-free tall fescue. The objective of this study was to determine if endophyte presence (E+) or absence (E-) in three tall fescue genotypes affects concentrations of acid detergent fiber (ADF), neutral detergent fiber (NDF), nitrogen (N), and phosphorus (P) in field and greenhouse studies. E+ plants had higher concentrations of ADF and NDF (nonsignificant in one genotype) in the field study. Endophyte lowered $\mathrm{N}$ concentration in the field from 19.2 to $18.5 \mathrm{~g} \mathrm{~kg}^{-1}$. Various interactions between genotype, endophyte, and maturity were significant for NDF, N, and P in both field and greenhouse studies. This interaction occurred because the effect of the endophyte increased or decreased fiber, $\mathrm{N}$, and $\mathrm{P}$ content of tall fescue depending upon plant genotype. This genotype by endophyte interaction should be kept in mind as novel endophytes are selected and placed into tall fescue cultivar selections, this interaction could alter fiber, $\mathrm{N}$ and $\mathrm{P}$ accumulation of the plants which depending upon plant genotype could result in a positive or negative response.

\section{Introduction}

Tall fescue (Lolium arundinaceum (Schreb.) Darbysh) is grown on approximately 14 million hectares in the United States. The majority of this acreage is infected with a fungal endophyte (Neotyphodium coenophialum (Morgan-Jones \& Gams.) Glenn, Bacon, \& Hanlin comb. nov.). This endophyte has been implicated as the causal agent of fescue toxicosis in animals grazing tall fescue [1-3]. Positive plant attributes are also associated with endophyte infection. These include resistance to grazing pressure [4-8], increased yields [9$11]$, resistance to insect attack $[7,12,13]$, and increased photosynthetic rates $[11,14]$. Endophyte infection increased seed production fitness in endophyte infected compared to endophyte free clones of the same genotype [15]. Presence of the endophyte has been shown to enhance plant persistence of infected plants by protecting plant roots in root-knot nematode infected soils [16]. Plants infected with endophyte have been shown to tolerate aluminum toxicity compared to nonendophyte-infected plants [17].
Some of the competitive advantages associated with endophyte infection could be due to the endophyte enhancing the ability of the infected plant to take up nutrients. The effect of endophyte on mineral accumulation and forage nutritive value has been inconsistent. A previous review noted that $\mathrm{P}$ concentrations were influenced by endophyte when plants were grown in a P deficient situation [18]. Endophyte infection decreased root diameter but increased root hair length and is theorized to act as a protection mechanism in P deficient soils [19]. It has been found that absorption of $\mathrm{Ca}, \mathrm{P}, \mathrm{Mg}$, and $\mathrm{K}$ is inconsistent between endophyte-infected plant genotypes $[18,20]$. The control and regulation of endophyte-produced alkaloids like ergovaline and peramine are affected by both plant and endophyte genotype [21]. Studies have shown that ADF and NDF are not influenced by the presence of endophyte $[7,12]$.

Limited research has been conducted on how nutrient accumulation differs with different genotypes and endophyte combinations. Identifying plant genotypes that are not enhanced by endophyte infection could lead to development 
of competitive EF lines. The objective of this study is to determine the effect of endophyte infection on fiber, $\mathrm{N}$, and $\mathrm{P}$ accumulation of tall fescue.

\section{Experimental Approach}

Three phenotypically distinct tall fescue plants (Plant), identified as 7, 17, and 22, of the variety "Kentucky 31 " were randomly selected from a nursery collection of 35 distinct plant types that were originally selected from a field that had been determined to have near $100 \%$ endophyte infection level. These plants had previously been vegetatively cloned into $\mathrm{EI}$ and $\mathrm{EF}$ forms of each plant $(7 \mathrm{E}+, 7 \mathrm{E}-, 17 \mathrm{E}+, 17 \mathrm{E}-$, $22 \mathrm{E}+$, and $22 \mathrm{E}-$ ) following published procedures [15]. For the field portion of the study, each plant $x$ endophyte combination was replicated 16 times and arranged as spaced plants on $61-\mathrm{cm}$ centers in a randomized complete block design on a Cecil sandy loam soil (fine, kaolinitic, and thermic Typic Kanhapludults) at the Simpson Agricultural Experiment Station near Pendleton, South Carolina. In fall of 1989, the whole plot area was fertilized with $45 \mathrm{~kg} \mathrm{ha}^{-1}$ each of $\mathrm{NH}_{4} \mathrm{NO}_{3}, \mathrm{P}_{2} \mathrm{O}_{5}$ and $\mathrm{K}_{2} \mathrm{O}$. In March, 1990 accumulated biomass from the fall and winter was removed by clipping all plants to a uniform $10-\mathrm{cm}$ height. Following the clipping all plants were fertilized with $50 \mathrm{kgha}^{-1}$ of $\mathrm{NH}_{4} \mathrm{NO}_{3}$ for production of fresh growth. Individual plant biomass was allowed to accumulate to April 3. At this point, plants were in a vegetative stage and each individual plant $x$ endophyte combination was hand clipped to a $10-\mathrm{cm}$ stubble height. Individual forage mass from each plant $x$ endophyte combination was placed into individual paper bags, labeled with the plant identification, and sent for drying. Plants were allowed to regrow to April 24 at which point the plants had entered the boot stage of maturity and reharvested following the same procedures as the April 3 harvest. Plants were again allowed to regrow to May 17 when plants were at fullbloom (mature) and harvested for the third time following previous harvest procedures.

For the greenhouse portion of the study, portions of the six plant $\times$ endophyte combinations from the field study were dug up and moved to the greenhouse in the spring of 1991. Tillers were removed from each plant $\times$ endophyte combination. Roots of the tillers were washed to remove field soil and the tillers were placed into $16-\mathrm{cm}$ pots containing washed sand. For a period of one month, plants were fertilized using a prepared $\mathrm{P}$ deficient nutrient solution (Table 1). Any additional water supplied to the plants was done using distilled deionized $\mathrm{H}_{2} \mathrm{O}$ to avoid the possibility of adding additional nutrients through the water. After one month, plants were then transplanted to $16-\mathrm{cm}$ pots with a mixture of $50 \%$ Cecil sandy clay loam (fine, kaolinitic, thermic Typic Kanhapludults) containing 2.24 and $41 \mathrm{~kg} \mathrm{ha}^{-1}$ of $\mathrm{P}$ and $\mathrm{K}$, respectively, and $50 \%$ washed sand limed at a rate of $2800 \mathrm{~kg} \mathrm{ha}^{-1}$ with $\mathrm{CaCO}_{3}$. Three treatment levels P (0, 22.40 (low) and 67.20 (high) $\mathrm{kg} \mathrm{ha}^{-1}$ ) in the form of $\mathrm{CaPO}_{4}$ were randomly assigned. Pots were then arranged in a randomized complete block design and replicated 5 times for a total of 90 plants ( 3 genotypes $(7,17$, 22) $\times 2$ endophyte levels $(\mathrm{E}+, \mathrm{E}-) \times 3$ P treatments $(0$, low, high) $\times 5$ replications). The $\mathrm{P}$ treatments were applied to the plants on a weekly basis for the length of the study plus the nutrient solution (Table 1). After a one month equilibration period, harvest was begun. The first greenhouse harvest was conducted when plants were in the vegetative stage. Total plant biomass from each individual plant $x$ endophyte $x$ $\mathrm{P}$ treatment combination was harvested to a $10-\mathrm{cm}$ stubble height and placed into individual bags, labeled, and sent to the dryer. Plants were allowed to regrow and harvested again at the boot stage followed by regrowth and a final harvest at plant maturity with each harvest following previous harvest procedures.

All individual plant samples from both the field and greenhouse were dried in a forced air oven at $66^{\circ} \mathrm{C}$ for one week, ground through a Wiley Mill (Thomas Scientific, Swedesboro, NJ) to pass through a $2 \mathrm{~mm}$ screen followed by a second grinding with a UDY cyclone mill (UDY Corp., Fort Collins, Colo) to pass through a $1 \mathrm{~mm}$ screen. Spectral reflectance data were collected on all individual samples using a Pacific Scientific Model 6250 scanning monochromator (Pacific Scientific Corp., Gardner/Neotec Instrument Div., Silver Spring, Md), from wavelengths 1100 to $2500 \mathrm{~nm}$ at $2 \mathrm{~nm}$ increments. Apparent reflectance data for the field and greenhouse harvests were stored in separate files.

A subset of samples was sent to the Clemson University Agricultural Service Laboratory for wet lab analysis of NDF, ADF, N, and P. Spectral data and wet lab chemical analysis data were used to develop multiple regression equations for determining mineral and fiber content of the remaining samples. Software used to collect reflectance spectra and to develop and test the equations is part of the USDA National NIRS Forage Network Software [22]. A portion of the total sample number was entered into SUBSET, part of the NIRS Forage Network Software which selected samples, based on spectra, for calibration equations. Separate equations were developed by the calibration program of the software package for each mineral and fiber fraction of the tall fescue samples. Equations were selected based on a combination of statistics generated from calibration and validation. Squared coefficients of multiple determination $\left(\mathrm{R}^{2}\right)$ for prediction were $0.83,0.87,0.94$, and 0.74 for ADF, NDF, N, and $\mathrm{P}$, respectively. Prediction equations were verified using a subset of 107 samples not used in equation development. Correlation $\left(r^{2}\right)$ values for predicted versus wet lab results were $0.89,0.88,0.95$, and 0.53 for ADF, NDF, N, and $\mathrm{P}$, respectively.

Field Data were analyzed using the PROC MIXED procedure of SAS [23] with replication considered a random effect and plant, maturity, and endophyte considered as fixed. Significant main effects and interactions were separated using the LS Means procedure. Main effects and interactions were considered significant when $P<.05$. In the greenhouse study, data were analyzed using the PROC MIXED procedure of SAS with replication considered a random effect and plant, maturity, endophyte, and $\mathrm{P}$ treatment considered as fixed. Main effects and interactions were separated using the LS Means procedure. Main effects and interactions were considered significant when $P<.05$. 
TABLE 1: Greenhouse nutrient solution.

\begin{tabular}{|c|c|}
\hline Ingredient & $\mathrm{mL} / \mathrm{liter}$ \\
\hline 1-M $\mathrm{KNO}_{3}$, potassium nitrate & 5 \\
\hline 1-M Ca $\left(\mathrm{NO}_{3}\right) \cdot 4 \mathrm{H}_{2} \mathrm{O}$, calcium nitrate & 5 \\
\hline 1-M MgSO $4 \cdot 7 \mathrm{H}_{2} \mathrm{O}$, magnesium sulfate & 2 \\
\hline $\begin{array}{l}\text { Microelement solution: } \\
2.5 \mathrm{~g} \mathrm{H}_{3} \mathrm{BO}_{3} / \text { liter of distilled deionized } \mathrm{H}_{2} \mathrm{O} \text {, boric acid } \\
1.54 \mathrm{~g} \mathrm{MnSO}_{4} / \text { liter of distilled deionized } \mathrm{H}_{2} \mathrm{O} \text {, manganese sulfate } \\
2.2 \mathrm{~g} \mathrm{Zn} \mathrm{SO}_{4} \cdot 7 \mathrm{H}_{2} \mathrm{O} / \text { liter of distilled deionized } \mathrm{H}_{2} \mathrm{O} \text {, zinc sulfate } \\
0.05 \mathrm{~g} \mathrm{CuCl}_{2} \cdot 2 \mathrm{H}_{2} \mathrm{O} \text { /liter of distilled deionized } \mathrm{H}_{2} \mathrm{O} \text {, copper chloride dihydride } \\
0.08 \mathrm{~g} \mathrm{MoO}_{3} / \text { liter of distilled deionized } \mathrm{H}_{2} \mathrm{O} \text {, molybdenum trioxide } \\
\end{array}$ & \\
\hline $\begin{array}{l}\text { Fe-tartartic acid solution: } \\
5 \mathrm{~g} \mathrm{FeCl}_{3} \text {, iron chloride } / 500 \mathrm{~mL} \text { of distilled deionized } \mathrm{H}_{2} \mathrm{O} \\
5 \mathrm{~g} \text { tartartic acid } / 500 \mathrm{~mL} \text { of distilled deionized } \mathrm{H}_{2} \mathrm{O} \\
\end{array}$ & 5 \\
\hline
\end{tabular}

Solution diluted $1: 1$ with distilled deionized $\mathrm{H}_{2} \mathrm{O}$.

TABle 2: Analysis of variance $P$-values for dry matter concentrations of ADF, NDF, N, and P content of endophyte infected and free tall fescue clones in the field study.

\begin{tabular}{|c|c|c|c|c|c|}
\hline Source & $\mathrm{df}$ & $\mathrm{ADF}$ & NDF & $\mathrm{N}$ & $\mathrm{P}$ \\
\hline Plant & 2 & 0.0011 & 0.0094 & $<.0001$ & $<.0001$ \\
\hline Endophyte & 1 & $<.0001$ & $<.0001$ & 0.0188 & 0.3247 \\
\hline Maturity & 2 & $<.0001$ & $<.0001$ & $<.0001$ & $<.0001$ \\
\hline Plant $\times$ endophyte & 2 & 0.3258 & 0.0025 & 0.2479 & $<.0001$ \\
\hline Plant $\times$ maturity & 4 & 0.1987 & 0.0265 & 0.0268 & 0.0089 \\
\hline Endophyte $\times$ maturity & 2 & 0.7842 & 0.1895 & 0.4743 & 0.1386 \\
\hline Plant $\times$ endophyte $\times$ maturity & 4 & 0.9343 & 0.8500 & 0.4413 & 0.7265 \\
\hline
\end{tabular}

\section{Results}

3.1. Field. Rainfall was $+62 \mathrm{~mm}$ above the 30 years normal for the period from January 1990 to May 1990. Temperature was $+1.49^{\circ} \mathrm{C}$ above normal for the same time period.

3.1.1. Plant, Maturity and Endophyte Effect on ADF. The main effects of plant, maturity, and endophyte all significantly $(P<.05)$ influenced ADF concentrations with no interactions present (Table 2). As plants matured ADF concentrations significantly increased (Table 3 ). EI plants had higher concentrations of ADF but, plant number 7 was significantly lower in ADF than 17 or 22 (Table 3).

3.1.2. Plant, Maturity, and Endophyte Effect on NDF. There were significant plant $\times$ endophyte and plant $\times$ maturity interactions that affected NDF concentrations (Table 2). Within plant, endophyte increased NDF concentrations of plant numbers $7 \mathrm{E}+$ and $22 \mathrm{E}+$ compared to their $\mathrm{E}-$ clones, but endophyte had no significant effect on NDF concentrations of plant 17 (Figure 1).

For the interaction of plant $\times$ maturity, no differences in NDF concentrations between plants was present at the vegetative stage but, at boot stage, genotype $7\left(555 \mathrm{~g} \mathrm{~kg}^{-1}\right)$ was lower $(P<.05)$ in NDF than $22\left(578 \mathrm{~g} \mathrm{~kg}^{-1}\right)$ or $17\left(561 \mathrm{~g} \mathrm{~kg}^{-1}\right)$. At maturity, genotype $22\left(627 \mathrm{~g} \mathrm{~kg}^{-1}\right)$ was higher $(P<.05)$ in NDF than $7\left(616 \mathrm{~g} \mathrm{~kg}^{-1}\right)$ or 17 $\left(615 \mathrm{~g} \mathrm{~kg}^{-1}\right)$. As plant maturity increased, NDF concentrations increased $(P<.05)$.

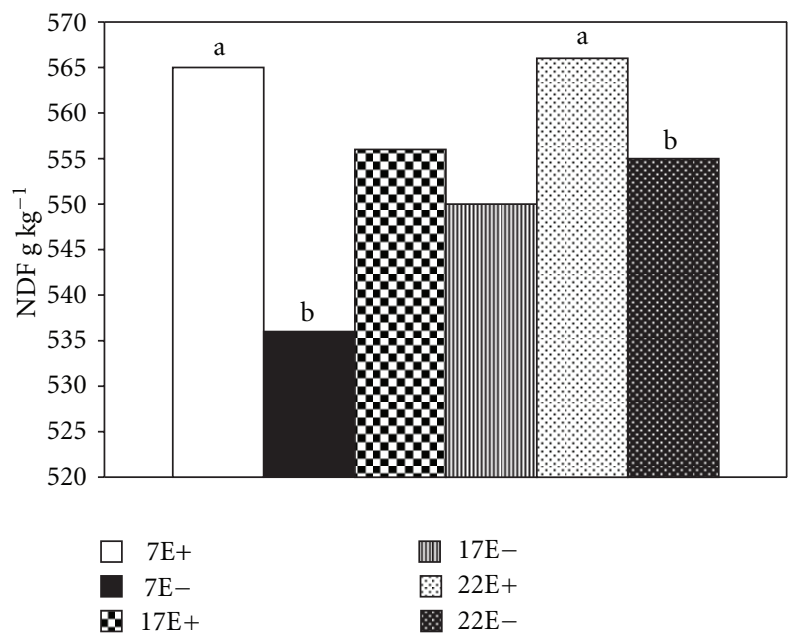

FIGURE 1: Plant $\times$ endophyte effect on $\mathrm{g} \mathrm{kg}^{-1}$ dry matter mean NDF concentrations from the field. Within plant, bars with different letters are significantly different at $P=.05$.

3.1.3. Plant, Maturity, and Endophyte Effect on $N$. EF plants were higher $(P<.05)$ in $\mathrm{N}$ than EI plants (Table 3). The plant $\times$ endophyte interaction was not significant (Table 2 ). The plant $\times$ maturity interaction was significant (Table 2 ). At the vegetative stage, plant $17\left(26 \mathrm{~g} \mathrm{~kg}^{-1}\right)$ was lower $(P<.05)$ in $\mathrm{N}$ content than 7 or $22\left(30 \mathrm{~g} \mathrm{~kg}^{-1}\right)$. At boot 
TABLe 3: Maturity, plant, and endophyte effect on ADF and N concentration of tall fescue from the field study.

\begin{tabular}{|c|c|c|c|c|c|c|c|c|}
\hline \multirow[b]{3}{*}{ Component } & \multicolumn{8}{|c|}{$\mathrm{g} \mathrm{kg}^{-1}$ dry matter } \\
\hline & \multicolumn{3}{|c|}{ Plant maturity } & \multicolumn{2}{|c|}{ Endophyte status } & \multicolumn{3}{|c|}{ Plant no. } \\
\hline & Vegetative & Boot & Mature & $\mathrm{E}+$ & $\mathrm{E}-$ & 7 & 17 & 22 \\
\hline $\mathrm{ADF}$ & $257^{c \dagger}$ & $272^{\mathrm{b}}$ & $302^{\mathrm{a}}$ & $281^{\mathrm{a}}$ & $274^{\mathrm{b}}$ & $273^{\mathrm{b}}$ & $278^{\mathrm{a}}$ & $280^{\mathrm{a}}$ \\
\hline $\mathrm{N}$ & $29.0^{\mathrm{a}}$ & $16.4^{\mathrm{b}}$ & $12.2^{\mathrm{c}}$ & $18.5^{\mathrm{a}}$ & $19.2^{\mathrm{b}}$ & $20.5^{\mathrm{a}}$ & $16.2^{\mathrm{b}}$ & $19.2^{\mathrm{a}}$ \\
\hline
\end{tabular}

${ }^{\dagger}$ Within row, means within column heading followed by differing letters are significantly different at $P=.05$.

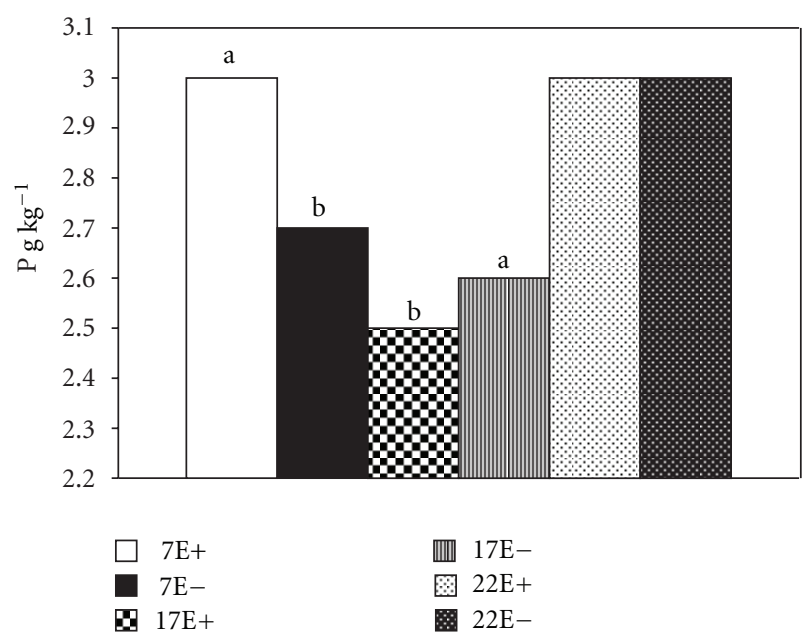

Figure 2: Plant $\times$ endophyte effect on $\mathrm{g} \mathrm{kg}^{-1}$ dry matter mean $\mathrm{P}$ concentrations from the field. Within plant, bars with different letters are significantly different at $P=.05$.

stage, plant $17\left(13 \mathrm{~g} \mathrm{~kg}^{-1}\right)$ was lower $(P<.05)$ in $\mathrm{N}$ content than $7\left(19 \mathrm{~g} \mathrm{~kg}^{-1}\right)$ or $22\left(17 \mathrm{~g} \mathrm{~kg}^{-1}\right)$. At maturity plant $17\left(9.1 \mathrm{~g} \mathrm{~kg}^{-1}\right)$ was lower $(P<.05)$ in $\mathrm{N}$ content than 7 $\left(13 \mathrm{~g} \mathrm{~kg}^{-1}\right)$ or $22\left(12 \mathrm{~g} \mathrm{~kg}^{-1}\right)$. Plant 17 was consistently lower $(P<.05)$ in $\mathrm{N}$ content than plants 7 or 22 across maturity groups.

3.1.4. Plant, Maturity, and Endophyte Effect on P. Plant $\times$ endophyte and plant $\times$ maturity interactions influenced $\mathrm{P}$ concentrations in the field (Table 2). For the plant $x$ endophyte interaction, plant 7E+ was higher in $\mathrm{P}$ than 7Ebut, in plant 17, E+ plants were lower in $\mathrm{P}$ than the $\mathrm{E}-$ clones. Endophyte presence or absence had no effect on $\mathrm{P}$ concentrations of plant 22 (Figure 2).

For the plant $\times$ maturity interaction at the vegetative stage, plant 22 was higher $\left(3.1 \mathrm{~g} \mathrm{~kg}^{-1}\right)$ in $\mathrm{P}$ content $(P<.05)$ than $7\left(2.6 \mathrm{~g} \mathrm{~kg}^{-1}\right)$ or $17\left(2.8 \mathrm{~g} \mathrm{~kg}^{-1}\right)$. At boot stage plants 22 $\left(2.8 \mathrm{~g} \mathrm{~kg}^{-1}\right)$ and $7\left(2.7 \mathrm{~g} \mathrm{~kg}^{-1}\right)$ were higher in $\mathrm{P}$ content $(P<$ $.05)$ than $17\left(2.3 \mathrm{~g} \mathrm{~kg}^{-1}\right)$. At maturity, plants $22\left(3.0 \mathrm{~g} \mathrm{~kg}^{-1}\right)$ and $7\left(3.0 \mathrm{~g} \mathrm{~kg}^{-1}\right)$ were higher in $\mathrm{P}$ content $(P<.05)$ than $17\left(2.6 \mathrm{~g} \mathrm{~kg}^{-1}\right)$. Plant 17 was consistently numerically lower in $\mathrm{P}$ concentrations across maturity groups, while 7 and 22 tended to be very similar in $\mathrm{P}$ concentration.

3.2. Greenhouse Results. The plant $\times$ endophyte interaction was significant for ADF, NDF, N, and P in the greenhouse

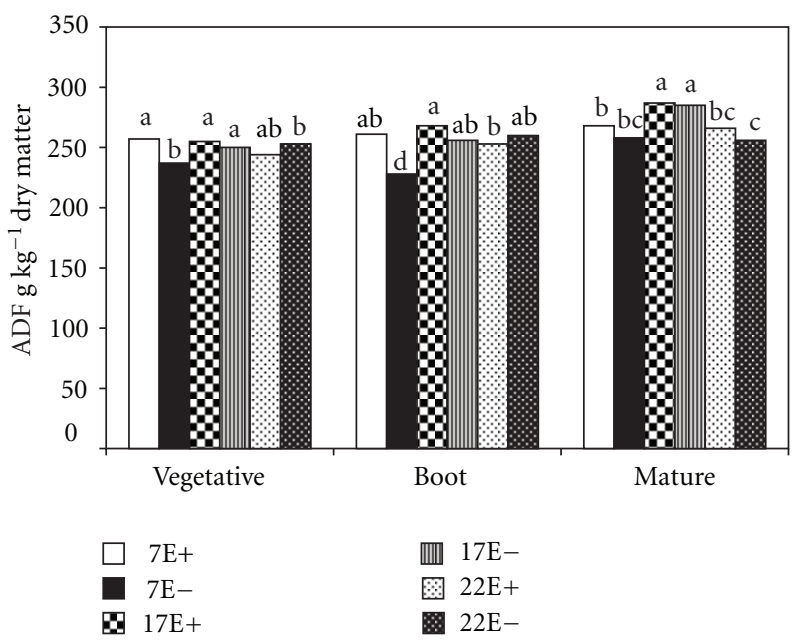

Figure 3: Plant $\times$ endophyte $\times$ maturity effect on $\mathrm{g} \mathrm{kg}^{-1}$ dry matter ADF concentrations from the greenhouse. Within maturity, bars with differing letters are significantly different at $P=.05$.

(Table 4). The plant $\times$ endophyte $\times$ maturity interaction was also significant for ADF, NDF, N, and $\mathrm{P}$ as in (Table 4) indicating that the plant $\times$ endophyte effect varied across maturity groups. Therefore, data will be presented in graphical form as plant $\times$ endophyte across maturity group.

\subsubsection{Plant, Maturity, Endophyte, and P Treatment Effect on} $A D F$. P treatment had no effect (Table 4) on greenhouse $\mathrm{ADF}$ concentrations. For the plant $\times$ endophyte $\times$ maturity interaction, plant $7 \mathrm{E}+$ was higher in $\mathrm{ADF}$ at the vegetative and boot maturity stage than $7 \mathrm{E}-$. There were no ADF concentration differences between $\mathrm{E}+$ and $\mathrm{E}$ - plants of 17 and 22 across maturity stages. $7 \mathrm{E}-$ tended to be lower numerically in ADF than other plant $\times$ endophyte combinations across maturity groups (Figure 3 ).

At the vegetative stage, plant 7 was lower $\left(247 \mathrm{~g} \mathrm{~kg}^{-1}\right)$ in $\operatorname{ADF}(P<.05)$ than plant $17\left(253 \mathrm{~g} \mathrm{~kg}^{-1}\right)$. Plant 22 $\left(249 \mathrm{~g} \mathrm{~kg}^{-1}\right)$ was not different from 7 or $17(P>.05)$. At boot stage, plant $7\left(245 \mathrm{~g} \mathrm{~kg}^{-1}\right)$ was lower $(P<.05)$ in mean concentrations of ADF than 17 or $22\left(262 \mathrm{~g} \mathrm{~kg}^{-1}\right.$ and $257 \mathrm{~g} \mathrm{~kg}^{-1}$, resp.). At maturity, plants 7 and $22\left(263 \mathrm{~g} \mathrm{~kg}^{-1}\right.$ and $261 \mathrm{~g} \mathrm{~kg}^{-1}$, resp. $)$ were lower $(P<.05)$ in mean ADF than $17\left(286 \mathrm{~g} \mathrm{~kg}^{-1}\right)$. As maturity increased from vegetative to mature $\left(249 \mathrm{~g} \mathrm{~kg}^{-1}, 254 \mathrm{~g} \mathrm{~kg}^{-1}\right.$, and $\left.270 \mathrm{~g} \mathrm{~kg}^{-1}\right)$, mean ADF concentrations increased $(P<.05)$. 
TABle 4: Analysis of variance $P$-values for dry matter concentrations of ADF, NDF, N, and P content of endophyte infected and free tall fescue clones in the greenhouse study.

\begin{tabular}{|c|c|c|c|c|c|}
\hline Source & $\mathrm{df}$ & $\mathrm{ADF}$ & NDF & $\mathrm{N}$ & $\mathrm{P}$ \\
\hline Plant & 2 & $<.0001$ & 0.0002 & $<.0001$ & 0.0011 \\
\hline Endophyte & 1 & $<.0001$ & 0.0028 & .0047 & 0.0070 \\
\hline Maturity & 2 & $<.0001$ & $<.0001$ & $<.0001$ & $<.0001$ \\
\hline $\mathrm{P}$ trt & 2 & 0.4675 & 0.8586 & $<.0001$ & 0.0031 \\
\hline Plant $\times$ endophyte & 2 & $<.0001$ & 0.0002 & 0.0002 & 0.0005 \\
\hline Plant $\times$ maturity & 4 & 0.0003 & 0.0103 & 0.2648 & 0.5425 \\
\hline Endophyte $\times$ maturity & 2 & 0.2741 & 0.6579 & 0.9190 & 0.3696 \\
\hline Plant $\times$ endophyte $\times$ maturity & 4 & 0.0080 & 0.0228 & 0.0051 & 0.0161 \\
\hline Plant $\times$ P trt & 4 & 0.0753 & 0.5002 & 0.0258 & 0.3851 \\
\hline E status $\times P$ trt & 2 & 0.0820 & 0.1778 & 0.7406 & 0.9525 \\
\hline Plant $\times$ endophyte $\times \mathrm{P}$ trt & 4 & 0.1568 & 0.7503 & 0.2646 & 0.3985 \\
\hline Maturity $\times \mathrm{P}$ trt & 4 & 0.0867 & 0.1442 & 0.0001 & 0.0021 \\
\hline Plant $\times$ maturity $\times \mathrm{P}$ trt & 8 & 0.3399 & 0.0639 & 0.4829 & 0.9244 \\
\hline Endophyte $\times$ maturity $\times \mathrm{P}$ trt & 4 & 0.1141 & 0.5705 & 0.1611 & 0.1796 \\
\hline Plant $\times$ Endophyte $\times$ maturity $\times$ P trt & 8 & 0.5522 & 0.6452 & 0.9616 & 0.9573 \\
\hline
\end{tabular}

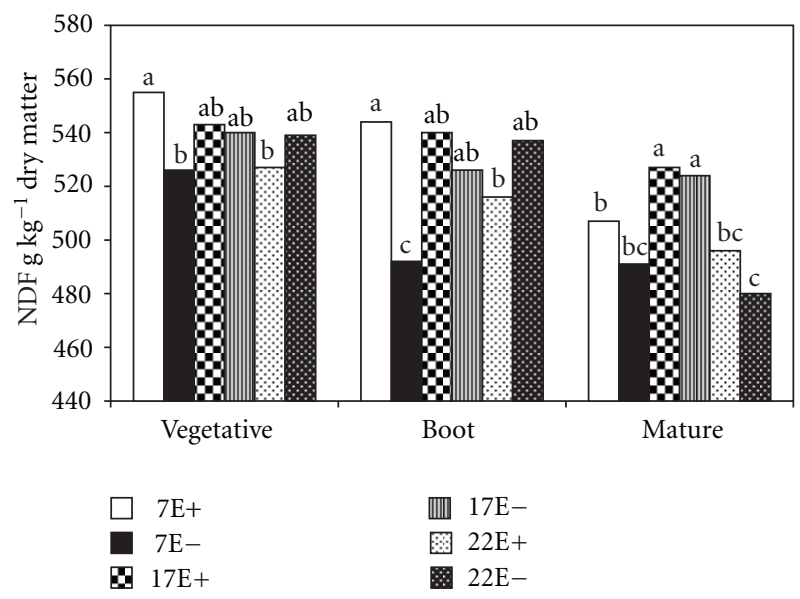

FIGURE 4: Plant $\times$ endophyte $\times$ maturity effect on $\mathrm{g} \mathrm{kg}^{-1}$ dry matter NDF concentrations from the greenhouse. Within maturity, bars with differing letters are significantly different at $P=.05$.

3.2.2. Plant, Maturity, Endophyte, and $P$ Treatment Effect on NDF. $\mathrm{P}$ treatment had no effect $(P>.05)$ on NDF concentrations. The plant $\times$ endophyte $\times$ maturity response for NDF was very similar to ADF. 7E+ was higher in NDF at the vegetative and boot maturity stages than 7E- (Figure 4). NDF concentrations of $17 \mathrm{E}+$ and $\mathrm{E}-$ were not different across maturity stages though $17 \mathrm{E}$ - tended to be numerically lower in NDF. No difference in NDF concentrations between $22 \mathrm{E}+$ and E- across maturity groups was noted as in (Figure 4).

There was no difference in total mean NDF concentrations between plants at the vegetative or boot stages $(P>$ $.05)$. At maturity, plant $17\left(526 \mathrm{~g} \mathrm{~kg}^{-1}\right) \mathrm{NDF}$ concentrations were higher $(P<.05)$ than 7 or $22\left(499 \mathrm{~g} \mathrm{~kg}^{-1}\right.$ and $488 \mathrm{~g} \mathrm{~kg}^{-1}$ resp.).

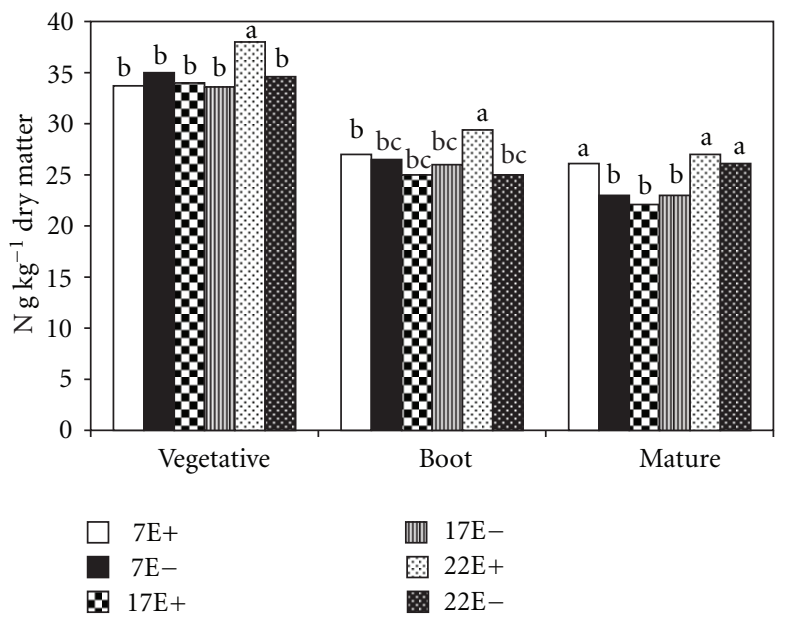

Figure 5: Plant $\times$ endophyte $\times$ maturity effect on $\mathrm{g} \mathrm{kg}^{-1}$ dry matter $\mathrm{N}$ concentrations from the greenhouse. Within maturity, bars with differing letters are significantly different at $P=.05$.

3.2.3. Plant, Maturity, Endophyte, and P Treatment Effect on $N$. For the plant $\times$ endophyte $\times$ maturity effect (Figure 5), endophyte did not influence $\mathrm{N}$ concentrations of plant 17 across maturity groups. At maturity $7 \mathrm{E}-$ plants were lower in $\mathrm{N}$ concentration than $7 \mathrm{E}+$ plants. At the vegetative and mature stages, $22 \mathrm{E}+$ plants were higher in $\mathrm{N}$ than the $22 \mathrm{E}$ - plants (Figure 5). Total mean N content of plant 22 $\left(30 \mathrm{~g} \mathrm{~kg}^{-1}\right)$ was higher $(P<.05)$ than $7\left(28.4 \mathrm{~g} \mathrm{~kg}^{-1}\right)$ which in turn was higher $(P<.05)$ than $17\left(27.1 \mathrm{~g} \mathrm{~kg}^{-1}\right)$. As maturity increased from vegetative to mature, mean $\mathrm{N}$ content of the plants decreased from $35.0 \mathrm{~g} \mathrm{~kg}^{-1}$ to $24.3 \mathrm{~g} \mathrm{~kg}^{-1}(P<.05)$.

A plant $\times P$ treatment and maturity $\times$ P treatment effect was significant (Table 4$)$. The high $\mathrm{P}$ treatment increased $(P<.05) \mathrm{N}$ concentration of plant $7\left(30.0 \mathrm{~g} \mathrm{~kg}^{-1}\right)$ compared to the low and $0 \mathrm{P}$ treatments $\left(27.0 \mathrm{~g} \mathrm{~kg}^{-1}\right.$ and $28.0 \mathrm{~g} \mathrm{~kg}^{-1}$ 


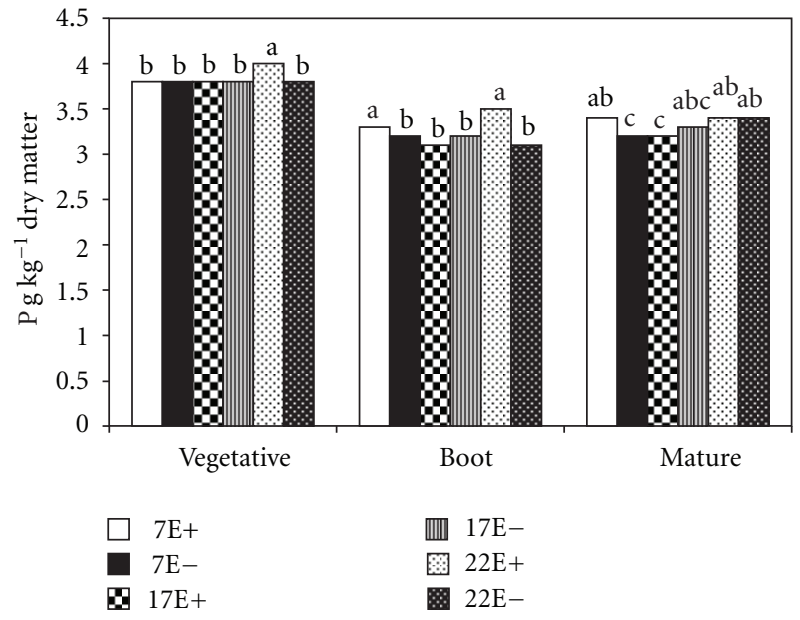

FIGURE 6: Plant $\times$ endophyte $\times$ maturity effect on $\mathrm{g} \mathrm{kg}^{-1}$ dry matter $\mathrm{P}$ concentrations from the greenhouse. Within maturity, columns with differing letters are significantly different at $P=.05$.

resp.). The high $\mathrm{P}$ treatment increased $(P<.05) \mathrm{N}$ concentration of plant $17\left(28.0 \mathrm{~g} \mathrm{~kg}^{-1}\right)$ compared to the low and $0 \mathrm{P}$ treatments $\left(26.0 \mathrm{~g} \mathrm{~kg}^{-1}\right.$ and $27.0 \mathrm{~g} \mathrm{~kg}^{-1}$ respectively). $\mathrm{N}$ concentrations of plant 22 were not influenced $\times P$ treatment $(P>.05)$.

At the vegetative stage, $\mathrm{P}$ treatment had no effect on $\mathrm{N}$ concentration $(P>.05)$. At boot stage the high $\mathrm{P}$ treatment plants $\left(29.0 \mathrm{~g} \mathrm{~kg}^{-1}\right)$ were higher $(P<.05)$ in $\mathrm{N}$ compared to $0\left(25.0 \mathrm{~g} \mathrm{~kg}^{-1}\right)$ or low $\mathrm{P}$ treatments $\left(27.0 \mathrm{~g} \mathrm{~kg}^{-1}\right)$. At maturity the high $\left(25.0 \mathrm{~g} \mathrm{~kg}^{-1}\right)$ and low $\left(24.0 \mathrm{~g} \mathrm{~kg}^{-1}\right) \mathrm{P}$ treatment plants were higher $(P<.05)$ in $\mathrm{N}$ concentration compared to the $0 \mathrm{P}$ treatment plants $\left(23.0 \mathrm{~g} \mathrm{~kg}^{-1}\right)$. The higher nutritional level of the low and high $\mathrm{P}$ treatment plants could explain increased $\mathrm{N}$ levels.

\subsubsection{Plant, Maturity, Endophyte, and P Treatment Effect} on $P$. The plant $\times$ endophyte $\times$ maturity interaction was significant for $\mathrm{P}$ concentration (Table 4 ). Across maturity stages plant 17 had no difference in $\mathrm{P}$ concentrations between $\mathrm{E}+$ and $\mathrm{E}-$. At the vegetative and boot stage $22 \mathrm{E}+$ was higher in $\mathrm{P}$ concentrations than the $22 \mathrm{E}-$ clones. At boot and mature stages, $7 \mathrm{E}+$ had higher $\mathrm{P}$ concentrations than the 7E-clones (Figure 6).

A maturity $\times \mathrm{P}$ treatment interaction was present for $\mathrm{P}$ (Table 4). P treatment had no effect on $\mathrm{P}$ concentrations at the vegetative stage or mature stage $(P>.05)$. At the boot stage the high $\mathrm{P}$ treatment $\left(3.4 \mathrm{~g} \mathrm{~kg}^{-1}\right)$ was higher $(P<$ $.05)$ in $\mathrm{P}$ than the low or $0 \mathrm{P}$ treatments $\left(3.2 \mathrm{~g} \mathrm{~kg}^{-1}\right)$. This difference though statistical is thought to have very little biological importance.

\section{Summary and Conclusions}

The main objective of this study was to determine if the tall fescue endophyte influenced the dry matter concentrations of ADF, NDF, N, and P within E+ and E- clones of the same plant genotype. Much of the earlier research where no endophyte effect was noted on these constituents did not look at the effect within individual plant genotypes as was done in this study [11]. A plant $\times$ endophyte interaction was significant for NDF and P in the field and ADF, NDF, N, and $\mathrm{P}$ in the greenhouse but, in the greenhouse the effect varied across maturity groups. This would indicate that variation does exist between genotypes and that the endophyte would have a greater affect on some genotypes than others. In our study the endophyte influenced fiber $\mathrm{N}$ and $\mathrm{P}$ concentrations of plant genotype 7 with a greater frequency than 17 or 22 . Genotype 7E+ plants had generally higher concentrations of ADF, NDF, and $\mathrm{P}$ in both the field and greenhouse. Plant genotype 17 was influenced the least by endophyte presence. In plant genotype 22 when interactions with endophyte were present the effect generally favored the $\mathrm{E}+$ clone. In previous work that included two of the genotypes of the current study ( 7 and 17), a plant genotype $\times$ endophyte interaction was present for morphological characteristics but the effect was not consistent across years nor for all characteristics measured [9].

Since variation does exist in the response to endophyte infection within plant genotypes, a more extensive survey of plant genotypes could be useful in the selection of endophyte free genotypes that could compete successfully with endophyte-infected genotypes. This genotype $\times$ endophyte interaction should be kept in mind as novel endophytes (low or zero ergovaline producing endophytes) are selected and placed into tall fescue cultivar selections, this interaction could alter fiber, $\mathrm{N}$, and $\mathrm{P}$ accumulation of the plants which depending upon plant genotype could result in a positive or negative response.

\section{References}

[1] D. M. Ball and C. S. Hoveland, "Toxic fescue solution: fungus implicated; control likely soon," Crops and Soils Magazine, vol. 35, no. 9, pp. 12-14, 1983.

[2] C. S. Hoveland, S. P. Schmidt, and C. C. King Jr., "Steer performance and association of Acremonium coenophialum fungal endophyte on tall fescue pasture," Agronomy Journal, vol. 75, pp. 821-824, 1983.

[3] J. C. Read and B. J. Camp, "The effect of the fungal endophyte Acremonium coenophialum in tall fescue on animal performance, toxicity, and stand maintenance," Agronomy Journal, vol. 78, pp. 848-850, 1986.

[4] J. H. Bouton, G. C. M. Latch, N. S. Hill et al., "Reinfection of tall fescue cultivars with non-ergot alkaloid-producing endophytes," Agronomy Journal, vol. 94, no. 3, pp. 567-574, 2002.

[5] M. E. Nihsen, E. L. Piper, C. P. West et al., "Growth rate and physiology of steers grazing tall fescue inoculated with novel endophytes," Journal of Animal Science, vol. 82, no. 3, pp. 878883, 2004.

[6] A. A. Hopkins, C. A. Young, D. G. Panaccione, W. R. Simpson, S. Mittal, and J. H. Bouton, "Agronomic performance and lamb health among several tall fescue novel endophyte combinations in the south-central USA," Crop Science, vol. 50, no. 4, pp. 1552-1561, 2010.

[7] J. C. Burns, D. S. Fisher, and G. E. Rottinghaus, "Grazing influences on mass, nutritive value, and persistence of stockpiled 
jesup tall fescue without and with novel and wild-type fungal endophytes," Crop Science, vol. 46, no. 5, pp. 1898-1912, 2006.

[8] M. R. Siegel, L. P. Bush, and D. D. Dahlman, "What am I losing by removing endophyte from tall fescue?" in Proceedings of the Southern Pasture and Forage Crop Improvement Association, pp. 41-44, Clemson, SC, USA, 1987.

[9] N. S. Hill, W. C. Stringer, G. E. Rottinhaus, D. P. Belesky, W. A. Parrott, and D. Pope, "Growth, morphological, and chemical component responses of tall fescue to Acremonium coenophialum," Crop Science, vol. 30, pp. 156-161, 1990.

[10] M. Arachevaleta, C. W. Bacon, C. S. Hoveland, and D. E. Radcliffe, "Effect of the tall fescue endophyte on plant response to environmental stress," Agronomy Journal, vol. 81, pp. 83-90, 1989.

[11] L. P. Bush and P. B. Burrus Jr., "Tall fescue quality and agronomic performance as affected by the endophyte," Journal of Production Agriculture, vol. 1, pp. 55-60, 1988.

[12] C. R. Funk, R. H. Hurley, J. M. Johnson-Cicalese, and D. C. Saha, "Association of endophytic fungi with improved performance and enhanced pest resistance in perennial ryegrass and tall fescue," Agronomy Abstracts, 1984.

[13] J. O. Fritz and M. Collins, "Yield, digestibility, and chemical composition of endophyte free and infected tall fescue," Agronomy Journal, vol. 83, pp. 537-541, 1991.

[14] L. P. Bush, S. G. Gay, and M. C. Johnson, "Growth and water use of endophyte-infected and endophyte-free tall fescue," University of Kentucky, Agronomy Journal Abstracts, 1988.

[15] J. S. Rice, B. W. Pinkerton, W. C. Stringer, and D. J. Undersander, "Seed production in tall fescue as affected by fungal endophyte," Crop Science, vol. 30, pp. 1303-1305, 1990.

[16] A. A. Elmi, C. P. West, R. T. Robbins, and T. L. Kirkpatrick, "Endophyte effects on reproduction of a root-knot nematode (Meloidogyne marylandi) and osmotic adjustment in tall fescue," Grass and Forage Science, vol. 55, no. 2, pp. 166-172, 2000.

[17] D. P. Malinowski and D. P. Belesky, "Tall fescue aluminum tolerance is affected by Neotyphodium coenophialum endophyte," Journal of Plant Nutrition, vol. 22, no. 8, pp. 13351349, 1999.

[18] D. P. Malinowski and D. P. Belesky, "Adaptations of endophyte-infected cool-season grasses to environmental stresses: mechanisms of drought and mineral stress tolerance," Crop Science, vol. 40, no. 4, pp. 923-940, 2000.

[19] D. P. Malinowski, D. K. Brauer, and D. P. Belesky, "The endophyte Neotyphodium coenophialum affects root morphology of tall fescue grown under phosphorus deficiency," Journal of Agronomy and Crop Science, vol. 183, no. 1, pp. 53-60, 1999.

[20] D. P. Malinowski, G. A. Alloush, and D. P. Belesky, "Leaf endophyte neotyphodium coenophialum modifies mineral uptake in tall fescue," Plant and Soil, vol. 227, no. 1-2, pp. 115126, 2000.

[21] J. T. Roylance, N. S. Hill, and C. S. Agee, "Ergovaline and peramine production in endophyte-infected tall fescue: independent regulation and effects of plant and endophyte genotype," Journal of Chemical Ecology, vol. 20, no. 9, pp. 2171-2183, 1994.

[22] J. S. Shenk and M. O. Westerhaus, "Accuracy of NIRS instruments to analyze forage and grain," Crop Science, vol. 25, pp. 1120-1122, 1985.

[23] SAS Institute, SAS/STAT User's Guide. Version 9.1, SAS Institute, Cary, NC, USA, 2003. 


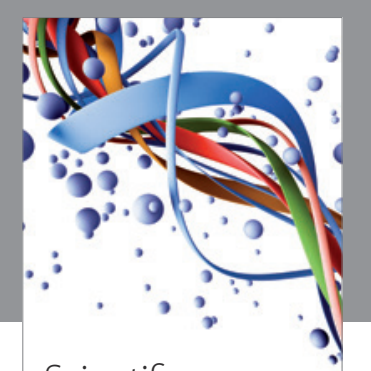

Scientifica
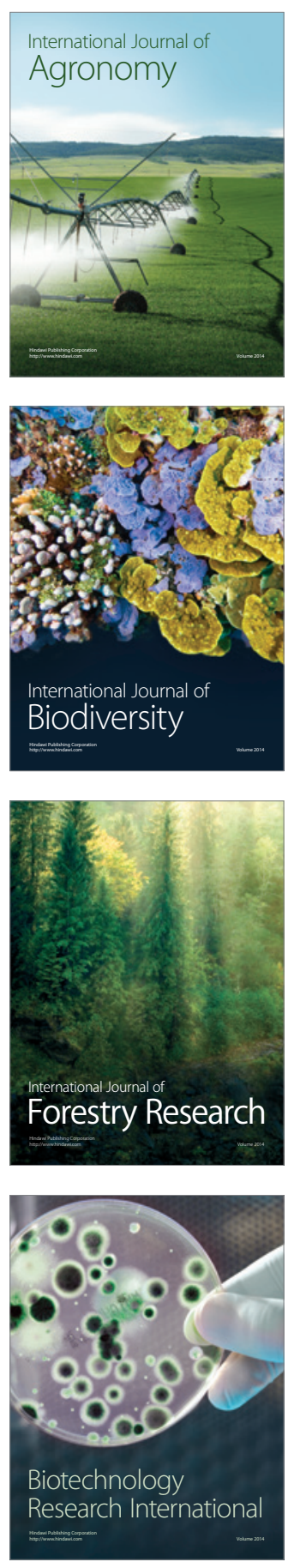
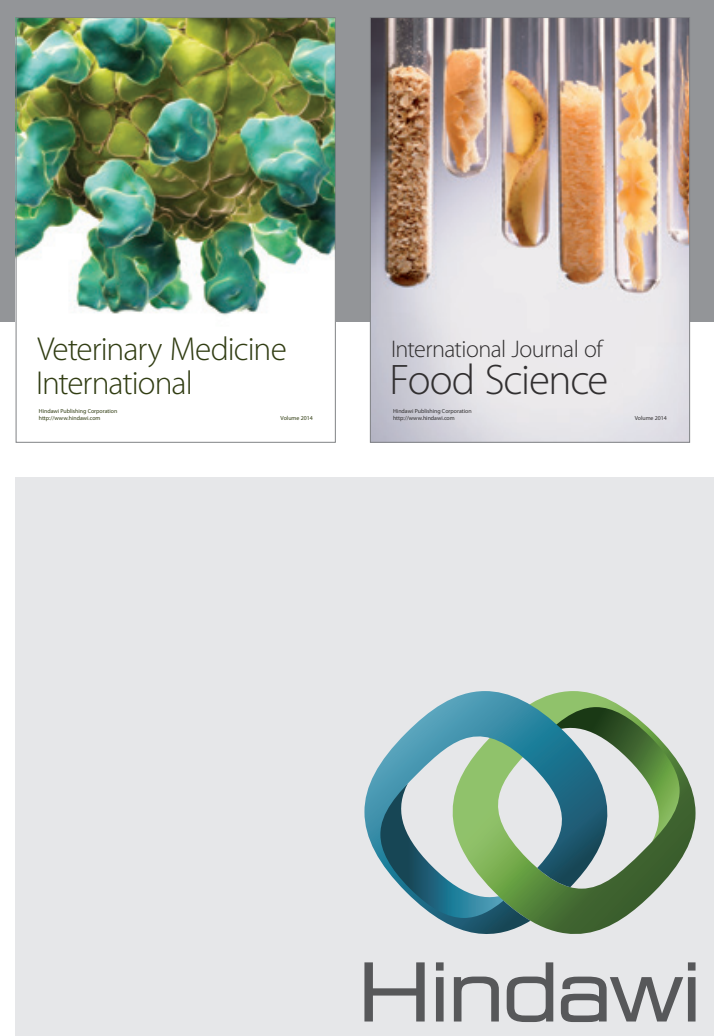

Submit your manuscripts at

http://www.hindawi.com
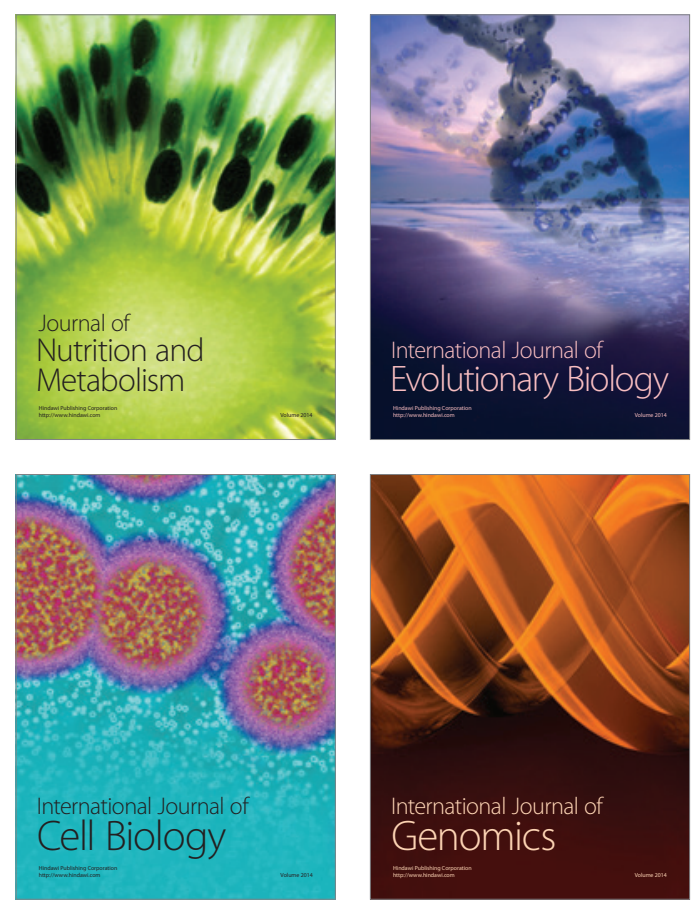
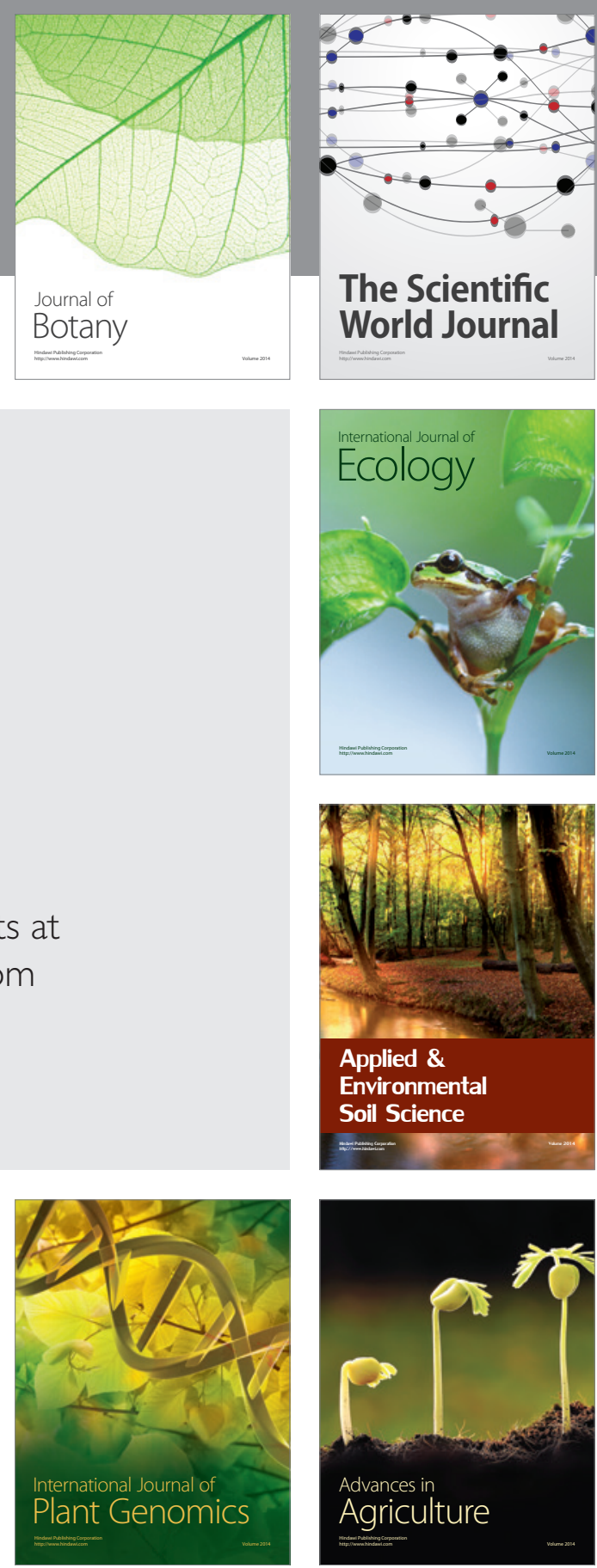

The Scientific World Journal
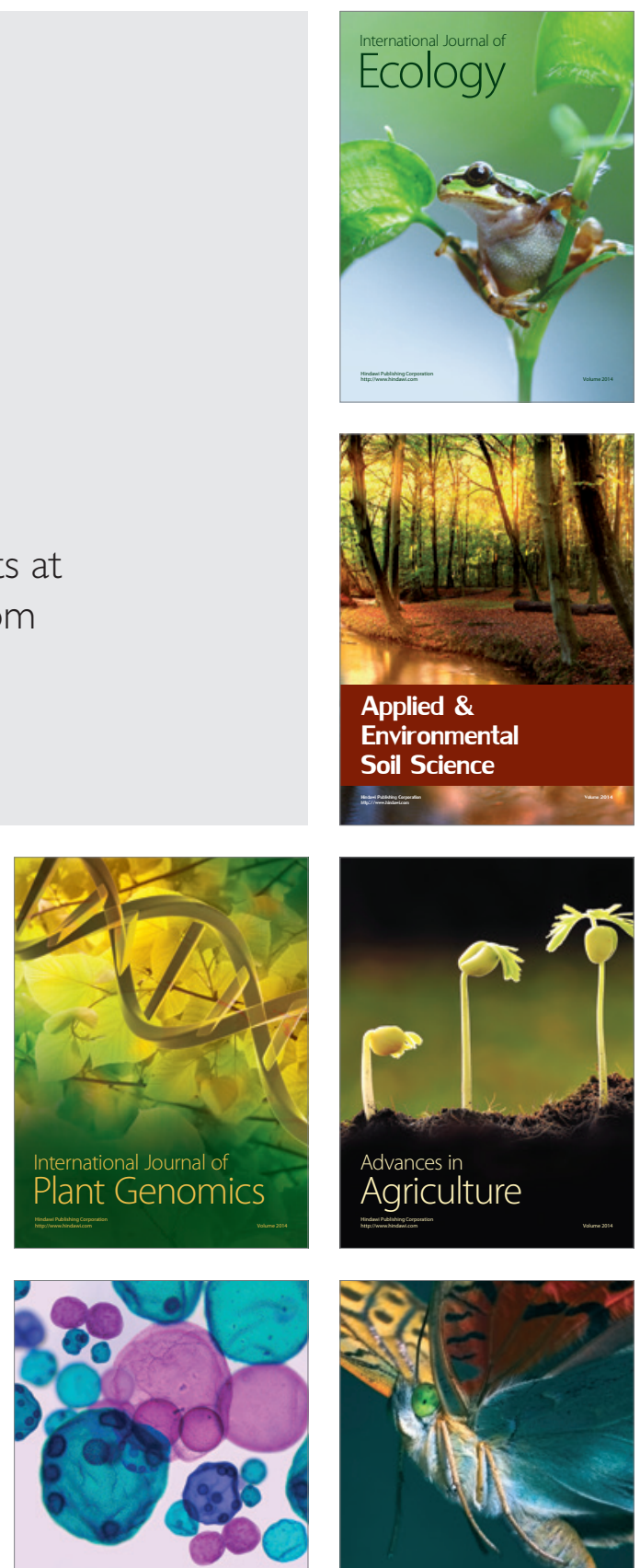

International Journal of Microbiology

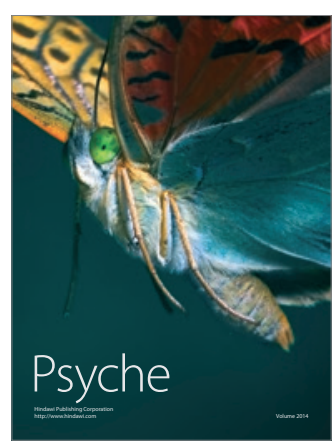

